\title{
STRATEGI PENGEMBANGAN PROFESIONALITAS GURU MELALUI PENDIDIKAN DAN PELATIHAN
}

\author{
${ }^{1}$ Wiwu Ulandari, ${ }^{2}$ Rustan Santaria \\ ${ }^{1}$ Institut Agama Islam Negeri Palopo \\ ${ }^{2}$ Institut Agama Islam Negeri Palopo \\ E-mail: wiwuwulandari101@gmail.com, rustan_santaria@iainpalopo.ac.id
}

\begin{abstract}
Abstrak
Salah satu kunci keberhasilan pendidikan adalah guru. Guru berperan penting dalam proses pembelajaran untuk meningkatkan mutu peserta didik. Maka dari itu profesionalitas seorang guru sangat penting untuk diperhatikan. Guru profesional adalah mereka yang mampu melaksanakan tugas sebagai pendidik dengan maksimal dengan memiliki kemampuan dan keahlian sebagai seorang pendidik. Penelitian ini merupakan penelitian pustaka (library research). Teori didapatkan dari data-data kepustakaan kemudian dikaji dan ditelaah dalam memperoleh konsepsi untuk mendapatkan hasil objektif. Adapun hasil dari penenlitian yakni untuk mewujudkan tujuan dari pendidikan maka diperlukan strategi pengembangan yang tepat dalam rangka meningkatkan profesionalitas guru. Dalam melaksanakan pendidikan dan pelatihan ada beberapa tahapan yang dilakukan yakni analisis kebutuhan, penentuan sasaran, penetapan isi program dan evaluasi program. Pendidikan dan pelatihan merupakan strategi pengembangan yang bertujuan untuk meningkatkan kompetensi guru baik dari pengetahuan, keterampilan maupun sikap.
\end{abstract}

Kata Kunci: Profesionalitas Guru, Pendidikan dan Pelatihan (Diklat)

\begin{abstract}
One of the keys of education success is the teacher. The teacher plays an important role in the learning process to improve the quality of students. Therefore the professionalism of a teacher is very important to note. Professional teachers are those who are able to carry out their duties as educators to the maximum by having the ability and expertise as an educator. This research is library research. The theory is obtained from the library data then investigated it to find out the conception objective result. The result of this research is to realize the goals of education, appropriate development strategies are needed in order to improve teacher professionalism. There are some step that have to done in holding education and training they are need analysis, goal setting, building program content and program evaluation. Education and training is a development strategy that aims to improve teacher competence in terms of knowledge, skills and attitudes.
\end{abstract}

Keywords: Teacher Professionalism, Education and Training

\section{Pendahuluan}

Pendidikan memegang peranan penting bagi kehidupan manusia dan juga merupakan kebutuhan yang mutlak untuk dipenuhi. Manusia memerlukan pendidikan untuk dapat maju dan sejahtera. Adapun tujuan pendidikan yaitu upaya peningkatan kualitas dan mutu sumber daya manusia sesuai yang diterangkan dalam Undang Undang (UU) Sistem Pendidikan 


\section{8 | Wiwu Wulandari, Rustan Santaria}

Nasional No. 20 Tahun 2003 yang tujuannya untuk perkembangaan potensi dari peserta didik agar menjadi manusia yang seutuhnya yang beriman dan bertaqwa kepada Tuhan Yang Maha Esa, berilmu, sehat,berakhlak mulia, mandiri, cakap, menjadi negara yang demokratis, bertanggungjawab, dan kreatif. Peranan Guru sangat penting dalamproses pembelajaran, dengan adanya pengembangan profesionalitas guru, diharapkan mampu melaksankan pembelajaran yang edukatif.

Ainon dkk, mengemukakan salah satu penentu keberhasilan pendidikan adalah guru. ${ }^{1}$ Usaha yang dapat dilakukan dalam meningkatkan kualitas sumber daya manusia khususnya guru harus dibina dan dikembangkan secara berkelanjutan. ${ }^{2}$ Untuk mencapai hal tersebut, diperlukan strategi dalam hal ini strategi mengembangkan profesionelisme seorang guru. Strategi yang dimaksudkan yaitu pendidikan dan pelatihan. Hasan mengemukakan pekerjaan seoramg guru akan semakin bertambah dengan adanya perkembangan teknologi, perubahan sosial, tuntutan sosial dan lain sebagainya maka dari itu diperlukan kemampuan untuk menghadapinya. ${ }^{3}$ Cara lembaga untuk mengantisipasi hal tersebut tiada lain yaitu mengupayakan cara untuk meningkatkan dan mengembangkan mutu pendidikan terutama sumber daya manusianya. Fasli Jalal mengemukakan pendidik yang profesional mampu menciptakan pendidikan yang bermutu dan berkualitas. ${ }^{4}$ Maka dari itu, dibutuhkan seorang pendidik yang memenuhi syarat agar tercipta guru yang bermutu sehingga mampu menghadirkan praktik dan sistem pendidikan yang bermutu.

Pentingnya penelitian ini dilakukan karena salah satu kunci membangun kualitas pendidikan. Pada Undang undang Nomor 14 Tahun 2005, tentang Dosen dan Guru, Guru diberikan penghargaan dan pengakuan serta beberapa peraturan perundangan lainnya. Guru merupakan profesi maka dari itu, diperlukan kemampuan guru dalam melakukan pekerjaannya dengan profesional. Seseorang dapat dikatakan profesional jika mampu mengerjakan tugas yang berpengang pada etika profesi, inovatif dalam mengerjakan tugas, produktif, efisien, efektif, independen dan inovatif. Kemudian profesional apabila berpegang pada prinsip-prinsip pelayanan yaitu sesuai teori yang sistematis dan unsur-unsur ilmu, memliki

${ }^{1}$ Ainon Mardhiah1, Yusrizal, Nasir Usman, Peningkatan Profesionalitas Guru Melalui Supervisi Akademik di SMP Negeri 3 Peusangan Kabupaten Bireun, diakses dari A Mardhiah, N Usman - Jurnal Administrasi Pendidikan ..., 2014 - jurnal.unsyiah.ac.id. Diakses pada tanggal 18 Maret 2020.

2Dalawi, Amrazi Zakso, Usman Radiana, Pelaksanaan Supervisi Akademik Pengawas Sekolah Sebagai Upaya Peningkatan Profesionalisme Guru SMP Negeri 1 Bangkayang, diakses dari http://jurnal.untan.ac.id/index.php/jpdpb/article/view/1576/1539, Vol 2, No 3 (2013). Diakses pada tanggal 18 Maret 2020.

${ }^{3}$ Hasan Hamid. Profesionalisme Guru dalam Implementasi Kurikulum Berbasis Kompetensi: Makalah Jurnal Himpunan Pengembang Kurikulum Indonesia (HIPKIN), (Bandung: HIPKIN, 2004).

${ }^{4}$ Fasli Jalal, Sertifikasi Guru untuk Mewujudkan Pendidikan yang Bermutu, (Artikel, Universitas Negeri Medan, 2007), h.1. 
kewenangan, diakui masyarakat serta memiliki kode etik. ${ }^{5}$ Dalam membangun pendidikan yang bermutu, guru merupakan aspek yang penting untuk diperhatikan, diperlukan kualitas guru yang mampu menciptakan pendidikan bermutu sehingga langkah strategis untuk menciptakannya dengan melakukan peningkatan mutu guru. Adapun upaya peningkatan yang dapat dilakukan dengan memberikan sertifikasi, melakukan uji kompetensi, serta mengikutkan guru dalam pelatihan dan penilaian kinerja guru. Guru sangat berpengaruh terhadap keberhasilan suatu sekolah, maka dari itu kualitas guru harus optimal. Pendidikan dan pelatihan merupakan salah satu bentuk peningkatan profesional. Bentuk pengembangan yang baik adalah pengembangan yang dilakukan sesuai kebutuhan kerja dan memiliki strategi yang tepat. Program yang dapat dilakukan yaitu pendidikan dan pelatihan.

Profesional adalah suatu pekerjaan yang dilakukan seseorang yang memerlukan kecakapan dan kompetensi yang sesuai dengan standar mutu serta memerlukan pendidikan profesi. ${ }^{6}$ Profesi merupakan suatu pekerjaan yang mensyaratkan seseorang untuk memiliki kompetensi. Jerry $\mathrm{H}$. Makawimbang mengemukakan guru yang profesional adalah guru yang memiliki keprofesionalan sebagai pendidik. ${ }^{7}$ Guru yang profesional yaitu yang mampu melakukan pembelajaran, memiliki pengalaman mengajar, memiliki pengetahuan, memiliki sikap teladan, kreativ dalam mengajar, kemampuan manajerial dan lain sebagainya. Guru profesional adalah mereka yang mampu melaksanakan tugas sebagai pendidik dengan maksimal dengan memiliki kemampuan dan keahlian sebagai seorang pendidik. Guru profesional adalah guru yang terlatih dan terdidik serta memilki pengalaman mengajar. Guru yang profesional dituntut untuk memiliki lima hal yaitu: ${ }^{8} 1$. Berkomitmen pada peserta didik dan proses belajarnya, 2 . Bertanggungjawab dalam hasil belajar peserta didik melalui evaluasi, 3 . Memiliki pemikiran yang sistematis dan belajar dari pengalamannya, 4 . Memiliki pengetahuan mengajar dan meguasasi teori yang diajarkan, 5 . Merupakan bagian dari masyarakat belajar sesuai profesinya.

Karakteristik profesionalitas guru juga dapat dilihat dari, a. Mampu melihat karakter setiap pendidik baik dari aspek fisik, intelektual, kultural, sosial, moral, dan emosional, b. Memiliki pengetahuan tentang teori beajar dan prinsip dalam mengajar, c. Melakukan pengembangan kurikulum sesuai bidang pengetahuannya, $d$. Melaksanakan program pengembangan yang mendidik, e. Mampu memnfaatkan teknologi demi pengembangan yang mendidik dan f. Memberikan fasilitas pada peserta didik dalam pengembangan potensi sehingga mampu mengaktualisasikan berbagai

${ }^{5}$ Sulipan, Kegiatan Pengembangan Profesi Guru 2007, Diakses melalui http://www. ktiguru.org/index.php/profesiguru. Ddiakses pada tanggal 18 Maret 2020.

${ }^{6}$ Undang-Undang Republik Indonesia Nomor 14 Tahun 2005 Tentang Guru dan Dosen. Diakses dari http://www.dikti.go.id/files/atur/UU14-2005Guru Dosen.pdf. Diakses pada tanggal 17 April 2020 pukul 10.00.

7Jerry H. Makawimbang, Supervisi dan Peningkatan Mutu Pendidikan, (Bandung, Alfabeta, 2011), h. 134.

${ }^{8}$ Supriadi, Mengangkat Citra dan Martabat Guru, (Yogyakarta: Adicita Karya Nusa, 1998). 
potensi yang dimiliki. Selain dari yang disebut, guru profesional harus juga didukung oleh kompetensi. Kompetensi seorang guru sesuai dengan Standar Nasioal Pendidikan diantaranya,

a. Kompetensi Pedagogik

Kompetensi pedagogik adalah kemampuan guru dalam proses pembelajaran baik dari pengelolaannya, perancangan dan pelaksanaannya, yang meliputi mampu memahami setiap peserta didik, merancang dan melaksanakan pembelajaran, melakukan evaluasi hasil belajar, dan melakukan pengembangan peserta didik dalam rangka meningkatkan potensi yang dimilikinya sesuai dengan evaluasi.

b. Kompetensi Kepribadian

Kompetensi kepribadian adalah kemampuan kepribadian yang menjadi teladan, mantap,stabil, berakhlak mulia arif, dewasa, dan berwibawa. Karena guru merupakan panutan yang diteladani peserta didik.

c. Kompetensi Profesioanal

Kompetensi profesional adalah Guru yang memenuhi standar kompetensi pendidik sehingga mampu melaksanakan proses pembelajaran dan menguasi materi secara luas dan mendalam.

d. Kompetensi Sosial

Kompetensi sosial adalah guru harus mampu bersosial dengan warga sekolah, karena profesinya mengharuskan guru unruk selalu berinteraksi dengan peserta didik, kepala sekolah, staf dan sesama pendidik.

Pendidikan merupakan upaya pengembangan kualitas dan potensi. Dalam Kamus Besar Bahasa Indonesia, pendidikan merupakan proses mengubah sikap dan usaha mendewasakan manusia. Sedangkan pelatihan merupakan berasal dari kata latihan yang berarti belajar dan membiasakan diri agar dapat malakukan sesuatu. ${ }^{9}$ Berdasarkan pengertian tersebut, pelatihan merupakan suatu proses pembinaan untuk mengembangkan kompetensi (pengetahuan, keterampilan, dan sikap/perilaku). Pendidikan dan pelatihan merupakan program yang terencana dengan tujuan untuk meningkatkan profesional, pengembangan pribadi, motivasi, meningkatkan mobilitas, tindakan yang remedial, keamanan anggota organisasi dan pemecahan masalah. ${ }^{10}$ Guru mengikuti pendidikan dan pelatihan untuk mengembangkan profesional dan kompetensinya sehingga mampu melaksanakan tugas-tugas sebagai Guru.

Sebelum pelatihan dilakukan, perlu untuk melakukan analisis kebutuhan dan beberapa tahap lainnya. Hasil analisis kebutuhan didasarkan pada kebutuhan peserta dan organisasi dan sesuai dengan potensi yang dimiliki, sehingga pelatihannya menguatkan dan menambah pengetahuan atau keterampilan itu sudah ada. Dalam konteks permintaan dan perilaku kerja, pelatihan untuk seseorang setidaknya meliputi orientasi deskripsi pekerjaan tugas tentang apa yang akan dikerjakan, kapan, bagaimana dan

${ }^{9}$ Kamus Besar Bahasa Indonesia, Arti KatanPendidikan dan Pelatihan, http://kbbi.web.id/pendidikan dan pelatihan. html. Diakses tanggal 25 Oktober 2019.

10Wahjosomidjo, Kepemimpinan Kepala Sekolah, (Jakarta: PT Raja Grafindo Persada, Ed.1, Cet.2, 2001) h. 381. 
dengan cara apa mereka mengevaluasi, pekerjaan yang sesuai perkembangan dan isu terkini selalu diikuti perusahaan. Memiliki keterampilan khusus untuk melakukan pekerjaan agar lebih efektif dan hal-hal yang menyangkut motivasi, nilai dan perilaku positif dalam pekerjaannya.

Wexley dan Yulk dikutip oleh Anwar Prabu Mangkunegara mengemukakan bahwa pelatihan dan pengembangan merupakan istilah yang saling berkaitan yaitu upaya atau usaha yang direncanakan untuk mencapai tujuan. ${ }^{11}$ Pelatihan ini bertujuan bagi peningkatan kompetensi dan keprofesionalan.

Berdasarkan berbagai pendapat tersebut dapat disimpulkan bahwa pendidikan dan pelatihan atau yang biasanya disebut diklat adalah upaya pengembangan atau program pengembangan yang bertujuan dalam peningkatan kompetensi guru dalam hal ini mampu meningkatkan pengetahuan dan keterampilan serta memperbiki perilaku. Dengan mengikuti pelatihan diharapkan guru dapat melaksanakan tugas dan tanggung jawabnya secara profesional. Pendidikan dan pelatihan juga merupakan bagian dari bentuk pengembangan sumber daya manusia dalam hal peningkatan kinerja.

1. Unsur- unsur dalam Pendidikan dan Pelatihan

Wahjosomidjo mengemukakan ada lima macam unsur penting demi terwujudnya program pelatihan yang efektif (essential elements), yaitu karakteristik para calon peserta, seperti: kesiapan mengikuti dan menerima latihan, latar belakang pengalaman, dan gaya yang cocok dalam proses belajar (principal characteristics), kompetensi pelatih/instructor, seperti kemampuan dan gaya mengajar serta kemampuan menggunakan metode pengajaran, waktu program pelatihan dilaksanakan, struktur waktu, lingkungan fisik berupa tempat dan situasinya, tata ruang, tempat duduk dan strategi pengajaran seperti tingkat partisipasi dan ketersediaan serta pemateri pendukung.

2. Tujuan dan Manfaat Pendidikan dan Pelatihan

Berdasarkan Peraturan Pemerintah tentang Diklat Jabatan Pegawai Negeri Sipil, adapun tujuan diklat yaitu: ${ }^{12}$

a. Meningkatkan kemampuan dan berptofesional dalam melaksanakan tugas baik dari pengetahuan, keahlian, dan keterampilan dengan berpegangan pada kepribadian dan etika PNS.

b. Menciptakan pegawai yang mampu merekatkan persatuan dan kesatuan bangsa serta mampu melakukan pembaharuan.

c. Memiliki semangat yang tinggi dan sikap dalam mengabdi pada pengayoman, pemberdayaan dan pelayanan masyarakat.

d. Dalam melaksanakan tugas, menciptakan pemikiran dan visi yang sama untuk terciptanya pemerintahan yang baik.

11Anwar Prabu Mangkunegara, Perencanaan dan Pengembangan Sumber Daya Manusia, (Bandung: PT Refika Aditama, 2003), h. 49.

12Peraturan Pemerintah (PP) No 101 Tahun 2000, Tentang Pendidikan dan Pelatihan (Diklat) Jabatan Pegawai Negeri Sipil, Pasal 2. 
Berdasarkan tujuan pendidikan dan pelatihan tersebut, menunjukkan bahwa pelatihan memiliki manfaat yang berpengaruh terhadap profesionalitas seseorang. Adapun tujuannya berfokus pada peningkatan dan pengembangan kompetensi. Beberapa pakar juga mengemukakan manfaat yang lain. Berikut ini manfaat diklat menurut Wursanto, yaitu: ${ }^{13}$

1. Pendidikan dan pelatihan mampu menciptakan hubungan pergantian dengan pegawai lainnya yang tidak hadir atau biasa disebut dengan peningkatan stabilitas pegawai.

2. Pendidikan dan pelatihan dapat membuat pegawai lebih kreatif serta mampu memperbaiki cara kerjanya dalam melaksanakan tugas.

3. Pendidikan dan pelatihan pastinya memberi manfaat terutama dalam pelaksanaan tugas akan bekerja lebih efektif dan efisien.

4. Pendidikan dan pelatihan akan memberi peluang bagi pegawai yang membutuhkan pengembangan diri.

Tujuan dan manfaat pendidikan dan pelatihan sangat berperan dalam peningkatan kinerja. Kompetensi akan meningkat apabila selalau di asah, upaya yang dapat dilakukan yaitu dengan mengikuti pengembangan. Pengembangan yang dimaksud adalah pendidikan dan pelatihan. Dengan mengikuti diklat, pegawai akan lebih mudah dalam bertugas dan menampilkan kienrja yang optimal. Organisasi khususnya lembaga pendidikan memiliki tanggungjawab yang besar dalam keberhasilam pendidikan di Indonesia, lembaga yang bermutu selalu ada dukungan dan kinerja dari pegawai yang bermutu pula. Guru sebagai pegawai di sekolah memiliki peranan yang penting dalam keberhasilan sekolah. Stakholder baik masyarakat, pemerintah dan orang tua sangat menaruh harapan yang besar pada guru. Maka dari itu, penting untuk lebih memperhatikan kinerja guru. Kinerja guru yang optimal akan membuat guru profesional dalam bekerja, sehinggan mampu mencapai tujuan pendidikan.

\section{Metode}

Jenis penelitian yang digunakan kepustakaan (Liberary Reserch), yaitu teori diambil dari data-data kepustakaan kemudian dikaji dan ditelaah dalam memperoleh konsepsi untuk mendapatkan hasil yang objektif. Pendekatan konten isi merupakan pendekatan untuk merekontruksi secara sistematis, akurat dan objektif, dalam penelitian ini digunakan pendekatan tersebut. Teknik pengumpulan data dalam penelitian ini yaitu teknik kepustakaan yakni mencari data mengenai hal-hal seperti buku-buku, catatan-catatan, notulen, surat kabar, agenda dan sebagainya. ${ }^{14}$

13 Wursanto, Manajemen Kepegawaian 1. (Yogyakarta: Kanisius. 1989), h. 60-61.

${ }^{14}$ Suharsini Arikunto, Prosedur Penelitian Pendekatan Praktik Edisi Revisi, (Jakarta: Rineka Cipta, 2010), h. 188. 


\section{Profesionalitas Guru}

Guru memiliki peranan penting dalam pengembangan mutu pendidikan. Guru diberikan predikat sebagai pahlawan tanpa tanda jasa karena tugasnya yang sangat mulia, memiliki tanggung jawab yang besar serta pengabdian yang luar biasa. Tujuan guru dalam memberikan pengajaran agar supaya terjadi perubahan dari pola pikir serta perilaku yang sesuai dengan yang diharapkan sebagai hasilnya. Kualitas pendidikan dimulai dari proses belajar mengajar dalam kelas. Hal ini berarti bahwa kualitas pendidikan diawali dengan proses pembelajaran yang dilakukan guru di dalam kelas. Untuk mencapai tujuan pendidikan dan menjalankan tugas sebagai guru, harus memiliki komepetensi sebagai pendidik. Kompetensi yang hasrus dimiliki guru berdasarkan undang-undang nomor 14 tahun 2005 tentang guru dan dosen yaitu kompetensi pedagogik, kompetensi kepribadian, kompetensi profesional dan kompetensi sosial. Untuk menjadi profesional keempat kompetensi tersebut sangat dibutuhkan. Maka dari itu Guru profesional merupakan guru yang yang melaksanakan profesi dan memiliki kemampuan dalam melaksanakan profesi tersebut.

Guru wajib melaksanakan tugas dengan sebaik-baiknya dengan membuat perencanaan pengajaran sehingga proses pengajaran berjalan dengan baik. Perencanaan pengajaran meliputi materi pembelajaran, tujuan, metode pengajaran yang digunakan, evaluasi hasil belajar serta perbaikan kembali berdasarkan evaluasi. Guru profesional dalam melaksanakan tugasnya memiliki sikap yang menunjang tinggi profesi dan karirnya. Mencapai tujuan, bersikap objektif, efektif dan efisien dalam berorientasi, transparan untuk memperaiki diri dan peserta didik dan inovasi merupakan sikap guru yang profesional. Selain kompetensi yang harus dimiliki, guru profesional juga perlu untuk memperhatikan:

\section{Dukungan Manajemen Kompetensi}

Kompetensi pada hubungan manajemen merupakan upaya yang dilakukan lembaga dan juga kemampuan dalam menjalin dan meningkatkan hubungan kerja sama dengan pihak dan instansi lain. Tujuannya untuk mendapatkan inovasi-inovasi yang mampu dikembangkan dan disosialisasikan guru maupun kepala sekolah. Kemampuan pengajaran dapat diciptakan guru melalu gerakan perubahan baru. Dengan kompetensi tersebut diharapkan mampu meningkatkan profesionalitas guru.

\section{Strategi Pengembangan}

Kepala sekolah juga memiliki peranan penting dalam meningkatkan profesionalitas guru. Dengan kepemimpinan yang baik akan mampu membuat guru lebih nyaman dalam melaksanakan tugasna. Seperti memberikan wewenang dan kepercayaan kepada guru dalam melaksanakan tugasnya sebagai seorang pendidik. Dengan adanya kepercayaan ini, dapat meningkatkan kepercayaan diri guru dalam mendidik sehingga mampu menampilkan profesionalitasnya sebagai guru.

\section{Supervisi Pengembangan}

Supervisi diperlukan guru untuk meningkatkan profesionalnya. Dengan adanya supervisi guru dapat memperbaiki diri untuk menjadi pendidik yang lebih baik. Supervisi juga dilakukan dengan memperhatikan 
latar belakang guru, karena pengalaman, pendidikan dan kemampuan guru berbeda. Hal ini penting untuk diperhatikan dalam melakukan supervisi guru yang didasarkan pada individual, komitmen dan keahlian. Keberagaman pendekatan supervisi salah satu alterntif untuk supervisor dalam melakukan supervisi pada guru yang berbeda-beda.

\section{Tindakan kelas}

Kepala dinas mengharapkan kepala sekolah mampu meningkatkan profesionalitas guru dalam pembelajaran di sekolah. Karena guru dapat dikatakan profesional apabila mampu meningkatkan kualitas dan mutu pembelajaran di kelas. Peserta didik akan berprestasi karena adanya motivasi belajar yang berjalan dengan menyenangkan, interaktif, inspiratif dan menantang.

\section{Pendidikan dan Pelatihan}

Pendidikan dan pelatihan merupakan upaya yang dilakukan untuk meningkatkan kualitas atau komeptensi seseorang. Begitupun dengan guru, pendidikan dan pelatihan sangat diperlukan guru dalam peningkatan profesional maupun kinerja. Pelatihan yang baik adalah pelatihan yang dilakukan berdasarkan kebutuhan sekolah maupun individu, untuk itu diperlukan analasis terlebih dahulu. Anaisis diperlukan untuk melihat kebutuhan guru dan pelatihan yang cocok karena setiap guru memiliki kemampuan maupun pengalaman yang berbeda.

Seperti yang kita ketahui, pendidikan dan pelatihan sangat penting bagi peningkatan profesionalitas maupun kinerja guru. Maka dari itu penting untuk pemerintah baik dari dinas pendidikan setempat termasuk juga kepala sekolah memperhatikan pendidikan dan pelatihan. Berdasarkan kenyataan dilapangan, masih ada beberapa guru yang tidak mengikuti pendidikan dan pelatihan dalam rangka meningkatkan kompetensi. Memang banyak guru yang mengikuti pelatihan, namun pelatihan yang dilakukan kurang merata serta tidak berkelanjutan, padahal pelatihan yang berkelanjutan akan mampu memberikan hasil yang baik bagi peningkatan kompetensi guru. Maka dari itu diharapkan pemeritah lebih memperhatikan guru untuk mengikuti pendidikan dan pelatihan karena memiliki tujuan dan manfaat yang sangat berpengaruh terhadap komeptensi guru.

Pendidikan dan pelatihan bukan hanya tanggungjawab pihak sekolah maupun dinas pendidikan namun juga penyelenggara pelatihan memiliki tanggungjawab yang sama. Karena salah satu kunci keberhasilan guru mengikuti pendidikan dan pelatihan karena adanya penyelenggara pendidikan pelatihan yang melaksakan tugas dengan baik. Maka dari itu, penyelenggara pendidikan dan pelatihan perlu merancangnya dengan sebaik mungkin. Untuk menciptakan pendidikan dan pelatihan, ada beberapa hal yang perlu untuk diperhatikan dalam pendidikan dan pelatihan yaitu: liaht di tahapan

\section{Analisis kebutuhan}

Analisis kebutuhan dilakukan untuk mendiagnosa kebutuhan dari peserta pelatihan. Kebutuhan yang mendasar yaitu masalah yang dihadapi 
guru sekarang dan tantangan yang akan dihadapi nantinya. Dengan analisis kebutuhan, tujuan pelatihan akan lebih mudah tercapai serta tepat sasaran.

\section{Penentuan sasaran}

Tahap selanjutnya penetapan peserta pelatihan dan melihat kebutuhan dari setiap peserta. Karena setiap peserta memiliki kebutuhan yang berbeda, maka dari itu penyelenggara harus lebih cermat termasuk dalam pemberian materi. Pada tahap ini, perekrutan dan penetapan pemateri juga harus diperhatikan, pemateri yang ditunjuk benar-benar memiliki kompetensi di bidang tersebut.

\section{Penetapan isi program}

Isi program sangat penting dalam pelatihan, maka dari itu perlu untuk membuat isi program yang kretaif mulai dari merancang lingkungan pelatihan karena lingkungan mempengaruhi peserta dalam mengikuti pelatihan nantinya, menetapkan metode-metode yang tepat digunakan selama memberikan materi pelatihan dan membuat materi yang sesuai dengan kebutuhan peserta.

\section{Evaluasi program}

Evaluasi program dilakukan untuk melihat sejauh mana keberhasilan dari pelatihan tersebut. Penting dilakukan untuk menguji program pelatihan yang diberikan mampu mencapai tujuan yang ditetapkan.

\section{Pendidikan dan Pelatihan sebagai Strategi dalam Meningkatkan Profesionalitas Guru}

Profesionalitas guru merupakan aspek yang penting dalam peningkatan mutu pendidikan. Kualitas pendidikan sangat bergantung pada guru. Pemerintah, masayrakat dan orangtua sangat menaruh harapan yang besar pada guru untuk dapat memberikan perubahan kepada peserta didik untuk memiliki perilaku dan pola pikir yang baik. Guru harus mampu melaksanakan tugasnya, maka dari itu diperlukan kompetensi diantaranya yaitu pedagogik, kepribadian, profesional dan sosial. Seorang guru harus memiliki pengetahuan dibidangnya, ini perlukan guru untuk melkaukan pembelajaran dengan efektif. Kepribadian yang baik akan memberikan dampak yang besar bagi peserta didik, guru dijadikan sebagai panutan dan dapat diteladani peserta didik. Kemampuan profesonal diperlukan agar guru memiliki tanggungjawab dan mampu melaksanakan profesinya sebagai guru. Kemampuan selanjutnya yaitu sosial, hal ini penting karena guru akan dihadapkan denga kondidi yang akan selalu terjadi interaksi. Guru harus mampu berinteraksi dengan peserta didik sehingga pelajaran yang disampaikan dapat tersalurkan.

Untuk menciptakan guru profesional, maka dari itu perlu strategi yang tepat dalam pengembangan profesionalitas. Salah satu strategi pengembangan yang tepat untuk meningkatkan profesionalitas guru yaitu dengan mengikuti pendidikan dan pelatihan. Pelatihan bertujuan untuk meningkatkan kompetensi, pastinya dengan mengikuti pelatihan profesionalitas guru akan meningkat. Pelatihan berokus untuk peningkatan 
dan pengembangan. Untuk meperbaiki profesionalitas guru. Guru harus mengikuti pendidikan dan pelaitahn yang berkelanjutan.

\section{Kesimpulan}

Guru profesional adalah mereka yang mampu melaksanakan tugas sebagai pendidik dengan maksimal dengan memiliki kemampuan dan keahlian sebagai seorang pendidik. Untuk menjadi guru profesional, ada lima karakteristiknya yaitu komitmen, tanggungjawab, memiliki pengetahuan, berpikir sistematis dan bagian dari lingkungan masyarakat. Hal lain yang perlu diperhatikan yaitu kompetensi, adapun kompetensi guru yaitu kompetensi pedagogik, kepribadian, profeional dan sosial.

Pendidikan dan pelatihan (diklat) merupakan salah satu strategi pengembangan yang bertujuan untuk meningkatkan kompetensi dalam hal ini pengetahuan, keterampilan dan sikap. Program diklat dilaksanakan berdasarkan analisis kebutuhan sekolah dan potensi yang dimiliki oleh guru. Salah satu strategi pengembangan profesionalitas guru yaitu pendidikan dan pelatihan. Pelatihan akan mampu meningkatkan profesionalitas guru karena tujuan pelatihan yaitu meningkatkan komeptensi. Untuk menjadi profesional, guru harus memiliki kompetensi sehingga mampu melaksanakan tugasnya.

Diharapkan pemerintah memberikan perhatian lebih terhadap pelatihan khususnya dinas pendidikan dan kepala sekolah serta memberikan pelatihan yang dibutuhkan baik guru maupun organisasi. Untuk penyelenggara pelatihan untuk menciptakan pelatihan nyaman bagi peserta. Peningkatan profesionalotas guru bukan hanya tanggungjawab kepala sekolah dan pemerintah namun juga guru tersebut. Guru harus memiliki kesadaran diri akan penting mengikuti pelatihan demi meningkatkan profesionalitas.

\section{Daftar Pustaka}

Hamid, Hasan. 2004. Profesionalisme Guru dalam Implementasi Kurikulum Berbasis Kompetensi: Makalah Jurnal Himpunan Pengembang Kurikulum Indonesia (HIPKIN), Bandung: HIPKIN..

Jalal, Fasli. 2007. Sertifikasi Guru untuk Mewujudkan Pendidikan yang Bermutu, Artikel, Universitas Negeri Medan.

Kamus Besar Bahasa Indonesia, Arti Kata Pendidikan dan Pelatihan, http://kbbi.web.id/pendidikan dan pelatihan. html. Diakses tanggal 25 Oktober 2019 pukul 19.27.

Makawimbang H. Jerry. 2011. Supervisi dan Peningkatan Mutu Pendidikan, Bandung, Alfabeta.

Mangkunegara, Prabu Anwar. 2003. Perencanaan dan Pengembangan Sumber Daya Manusia, Bandung:PT Refika Aditama. 
Mardhiah, Ainon, Yusrizal , Usman Nasir. 2014. Peningkatan Profesionalitas Guru Melalui Supervisi Akademik di SMP Negeri 3 Peusangan Kabupaten Bireun, diakses dari A Mardhiah, N Usman- Jurnal Administrasi Pendidikan ..., - jurnal.unsyiah.ac.id. Diakses pada 18 Maret 2020.

Peraturan Pemerintah (PP) No 101, Pasal 2, Tahun 2000, Tentang Pendidikan dan Pelatihan (Diklat) Jabatan Pegawai Negeri Sipil.

Sulipan, 2007, Kegiatan Pengembangan Profesi Guru, Diakses melalui http://www. ktiguru.org/index.php/profesiguru. Diakses pada 18 Maret 2020.

Supriadi. 1998. Mengangkat Citra dan Martabat Guru, Yogyakarta : Adicita Karya Nusa.

Undang-Undang (UU) Republik Indonesia (RI) Nomor 14 Tahun 2005 Tentang Guru dan Dosen. Diakses dari http://www.dikti.go.id/files/atur/UU14-2005Guru Dosen.pdf. Diakses pada 17 April 2020.

Wahjosomidjo. 2001. Kepemimpinan Kepala Sekolah, Jakarta: PT RajaGrafindp Persada, Ed.1, Cet.2.

Wursanto. 1998. Manajemen Kepegawaian 1, Yogyakarta: Kanisius.

Zakso , Amrazi Dalawi, Radiana Usman, Pelaksanaan Supervisi Akademik Pengawas Sekolah Sebagai Upaya Peningkatan Profesionalisme Guru SMP Negeri 1 Bangkayang, diakses dari http://jurnal.untan.ac.id/index.php/jpdpb/article/view/1576/1539, Vol 2, No 3 (2013), Diakses pada 18 Maret 2020. 
68 | Wiwu Wulandari, Rustan Santaria

HALAMAN INI SENGAJA DIKOSONGKAN 